\title{
Leading sustainable neighbourhoods in Europe: Exploring the key principles and processes
}

Local projects involving sustainable urban transformation are increasingly prominent in cities and towns, and are often referred to as sustainable neighbourhoods. These initiatives have been described as experiments in urban sustainability and could provide concrete answers to many challenges facing cities and society. This article investigates the design and development of two leading examples of sustainable neighbourhoods that used different implementation strategies: a top-down development in Western Harbour (Swed. Västra Hamnen, Malmö) and a bottom-up (participatory) approach in Vauban (Frei- burg). The article investigates how the initial implementation approach in sustainable urban redevelopment influenced and conditioned the urban design, social sustainability and local governance of the neighbourhoods. The research also focuses on how Vauban and Western Harbour have influenced and disseminated sustainable urban solutions to other urban contexts.

Keywords: sustainable neighbourhoods, sustainable urban development, new urbanism principles, urban experimentation processes, eco labs, Vauban, Western Harbour 


\section{Introduction and background}

Small-scale community sustainability initiatives of various types (typically small cities, villages and neighbourhoods) have become increasingly common over the past decade (Forrest \& Wiek, 2014). Local projects involving sustainable urban transformation in cities are often referred to as sustainable neighbourhoods. Such developments could represent a holistic solution for new sustainable urban balances at the local level (Rudlin \& Falk, 2009). David Harvey (1990) defines a sustainable neighbourhood as an independent urban area within a city that preserves the symbolic richness of the traditional urban form and that is based on dialogue and diversity. The creation of sustainable neighbourhoods and the development of local urban communities involve setting clear and robust environmental, social and economic objectives that are ideally in constant equilibrium (Churchill \& Baetz, 1999). Harriet Bulkeley et al. (2015) claim that the constellation of interventions that together form the urban climate change governance landscape is often explicitly experimental in character, seeking to develop, try and attest to the experience of responding to climate change. Sustainable neighbourhoods can be framed as experiments or living labs providing concrete answers to many challenges facing cities and society. This particular form of development could become a new active urban model, in line with current sustainable development principles. Ideally, sustainable neighbourhoods embody alternative solutions to current unsustainable practices in cities.

From a literature review of sustainable neighbourhoods, it is possible to conclude that most examples of sustainable neighbourhoods in Europe are being implemented in northern and western Europe (Medved, 2016). Consequently, Stella Kyvelou et al. (2012) define the sustainable neighbourhood concept as a northern European model. Southern European sustainable neighbourhoods have great potential, but are rarely cited or mentioned as best-practice examples, and they are not often analysed in the literature on urban sustainability. The best examples of sustainable neighbourhoods (from northern and western Europe) are often grouped, analysed or cited together. The most often recognised and thus cited leading examples of sustainable neighbourhood implementation, as identified in Primož Medved's (2016) extensive literature reviews, have been established in: Culemborg (the Netherlands: EVALanxmeer), Utrecht (the Netherlands: Leidsche Rijn), Amsterdam (the Netherlands: GWL Terrein), Malmö (Sweden: Western Harbour and Augustenborg), Stockholm (Sweden: Hammarby Sjöstad), Freiburg (Germany: Vauban, Rieselfeld and Weingarten) Hannover (Germany: Kronsberg), Ostfildern (Germany: Scharnhauser Park), Tübingen (Germany: Französisches Viertel - Südstadt), Helsinki (Finland: Viikki),
Copenhagen (Denmark: Vasterbo), Sutton (UK: BedZed), London (England: Greenwich Millennium Village) and Linz (Austria: SolarCity). However, large differences exist between the case studies, especially in terms of communityrelated "social sustainability" and governance issues. Most of the acclaimed sustainable neighbourhoods have shown superior excellence in terms of environmental sustainability, but it seems that social sustainability and the local governance system have not been developed systematically in some cases.

\section{Research aims}

Two contextual circumstances shaped the hypotheses and the research aims of this article. First, based on a preliminary analysis of various sustainable urban communities, the author discovered a potential correlation between a strong cohesive urban community, local governance and the initial implementation approach in urban planning. Several urban researchers have also identified this particular correlation. For example, Hugh Barton et al. (2003) claimed that the more the local community is involved in the design and development process of the neighbourhood, the greater the likelihood is that they will create a place that has local relevance. Hildebrand Frey (1999) noted that people in a neighbourhood are more responsible and connected if they have been involved in shaping the neighbourhood. Participatory urban design supported by workshops, communication forums and competitions was found to increase the sense of the local urban community and commitment to the sustainable urban project (Bayulken \& Huisingh, 2015). Strengthening participation in local governance is correlated with direct citizen involvement in making decisions. Local governance calls for increased participation of civil society, which traditionally formed part of the public sphere (Gaventa \& Valderrama, 1999).

Based on these theoretical assumptions, the author formulates two research hypotheses:

1. Sustainable neighbourhoods implemented through a participatory bottom-up approach have developed more human-scale, community-oriented urban forms in comparison with top-down sustainable neighbourhoods.

2. Sustainable neighbourhoods implemented through a participatory bottom-up approach are more socially sustainable and have developed a stronger and more complex local urban governance system in comparison with top-down sustainable neighbourhoods.

In order to analyse the implications and confirm the two hypotheses, two leading sustainable neighbourhoods that have used completely different implementation approaches were chosen: Vauban (in Freiburg, Germany) and Western Har- 
bour (in Malmö, Sweden). For more information, see Section 3 "Approach and methodology". This article first explores and analyses the two sustainable neighbourhoods using unique methodological approaches and investigates whether (and how) the initial implementation approach has conditioned the urban design (Hypothesis 1), social sustainability and especially community involvement in everyday decision-making or the local governance of both neighbourhoods (Hypothesis 2).

The second contextual circumstance the article focuses on is related to the contemporary observation that, with the current rapidly increasing urbanisation rate, it is critically important to take collective action through bottom-up participation and top-down commitment to establish more cases of sustainable urban projects and create mainstream living examples that can share their sustainable urban innovations (Bayulken \& Huisingh, 2015). Based on this, the article's second research aim is to identify whether (and how) the two cases have already influenced and disseminated sustainable urban solutions to other urban situations. The author explores whether there is a significant difference related to the transfer of knowledge between the two case studies with a completely different implementation process.

\section{Approach and methodology}

From among the best examples of sustainable neighbourhoods mentioned in the introductory section, two case studies were chosen for comparative analysis (Bächtold, 2013; Fraker, 2013; Medved, 2016). The first is one of the best-known leading sustainable neighbourhoods developed using the bottom-up approach: Vauban (in Freiburg, Germany). The second is one of the most representative sustainable neighbourhoods developed using the top-down approach: Western Harbour (in Malmö, Sweden). These two neighbourhoods represent practical prototypes of how a sustainable neighbourhood can be designed and developed using the top-down and bottom-up implementation approaches (Bächtold, 2013; Fraker, 2013). Vauban and Western Harbour represent two extremes in relation to urban development implementation strategies. "Atypical or extreme cases often reveal more information because they activate more actors and more basic mechanisms in the situation studied" (Flyvbjerg 2006: 229). Certainly, an analysis based on only two case studies will not make a "universal" statement, but it can still open up new perspectives for further analysis and discussion.

To address the first hypothesis, the comparative analysis of the two sustainable neighbourhoods is based on the "new urbanism principles" analytical framework (CNU \& HUD, 2000; Grant, 2006; Rahnama et al., 2012; Internet 1). To address the second hypothesis, the analytical framework of "processes for urban experimentation" was chosen (Bulkeley et al., 2015). The new urbanism principles framework was selected because new urbanism is one of the main contemporary movements that focuses on how to recreate and generate human-scale dense developments in cities. New urbanism promotes specific urban design elements that should be adapted to local needs (and not vice versa). New urbanism calls for a more human scale, walkable streets, mixing shops and residences to generate city life, higher density and a less automobile-dominated community (Kushner, 2002). The new urbanism framework was also chosen because it integrates most of the parameters and important basic elements of the compact city framework (Rogatka \& Ramos Ribeiro, 2015). The new urbanism principles framework made it possible to address the first hypothesis and eventually confirm that sustainable neighbourhoods implemented with a participatory bottom-up approach have developed more community-oriented, human-scale urban forms in comparison with top-down sustainable neighbourhoods. The comparative analysis starts by examining the basic characteristics and urban design features of Western Harbour and Vauban. After presenting the two neighbourhoods, it uses the checklist in Table 1 to identify whether the neighbourhoods have implemented features that are in line with new urbanism principles. The comparison research elements include the ten principle definitions described in the second column of $\mathrm{Ta}^{-}$ ble 1 (Section 4). In this way, it is possible to better understand the main sustainable characteristics of both urban areas and to establish the development level toward the urban-planning ideals advanced by the new urbanism movement. The analysis highlights the physical environment of the neighbourhoods and the sustainable goals they achieve, especially those related to urban design and sustainable transport.

Processes for urban experimentation were selected because they appear to be absent from other frameworks on cities and because the framework offers an important perspective on the dynamic relation between various stakeholders through time. Nuno Ferreira da Cruz and Rui Cunha Marques (2014) noted that nowadays social, economic and environmental performance is not sufficient to judge the actions of a local authority; it should also be evaluated by its conduct and the way it actually carries out its responsibilities. For this reason it is important to include an analysis of local governance, which relates to the behaviour of institutions, the governing processes and the relations between the state (municipality), the citizens and other stakeholders (Ferreira da Cruz \& Marques, 2014). Local governance at the neighbourhood level is highlighted through the processes framework. Analysis of the processes framework by Bulkeley et al. (2015) makes it possible to address the second hypothesis and confirm that sustainable neighbourhoods implemented with a participatory bottom-up 
approach are more socially sustainable and have developed a stronger and more complex local urban governance system in comparison with top-down sustainable neighbourhoods. For the processes underpinning sustainable neighbourhoods (Section 5), the analysis focuses on the following activities: making, maintaining, living and disseminating. The "processes" section derives from Bulkeley et al. (2015), who identify making, maintaining and living as key aspects of urban experimentation. The author adds disseminating as an innovative additional process to investigate how sustainable neighbourhoods evolve and influence other urban developments. With the innovative disseminating process, it is possible to achieve the second research aim and identify whether the initial implementation approach influences the transfer of sustainable urban solutions to other urban realities. In this section, the criteria of comparison for the two sustainable neighbourhoods are the four $(3+1)$ processes themselves (see the definition of processes in $\mathrm{Ta}$ ble 2 , Section 5 ). The process analysis provides an innovative overview of the dynamic formation of the local governance system through time. In this way it is possible to understand how (and whether) the initial implementation approach (the "making" process) in the selected case studies determined social sustainability and local governance within the subsequent processes (maintaining, living and disseminating).

The data collection methods include interviews with key stakeholders, site visits in Vauban and Western Harbour, and literature reviews focused on the case studies. The author visited both sustainable neighbourhoods, where he had the opportunity to gain first-hand experience of the neighbourhoods as living environments, collect audio and graphic material, interview key stakeholders, make site visits and develop the case studies. In April 2013, the author visited and stayed in Vauban (Freiburg) for two weeks. From March to May 2014, he visited Western Harbour nine times. He had the opportunity to interview the main urban developers, municipality representatives and main representatives of local community groups in order understand the role of all of the stakeholders involved in developing the neighbourhood. Interviews primarily focused on municipal staff involved in developing the projects, as well as, in the case of Vauban, local opinion leaders and local associations' representatives. In Western Harbour, he could not interview local citizen representatives because the neighbourhood has no community centres or local community associations. In Vauban in Freiburg, the author had the opportunity to interview Wulf Daseking (the urban planner of the Municipality of Freiburg, who planned the entire sustainable neighbourhood), Andreas Delleske (the leader of the community initiative Forum Vauban) and Sigrid Gombert (former editor of the local newspaper Vaubanactuel). In Western Harbour in Malmö, he interviewed Eva Dalman (the former project manager of the Bo01 project in Western Har- bour), Maria Lööf (working at the Municipality of Malmös Environment Department) and Jan Johansson (working at the Municipality of Malmö's Real Estate Department). All of the interviews were based on the same open-ended structured questionnaire. The questions covered the points of interest presented in Medved's (2016) structural model of an autonomous sustainable neighbourhood and refer to topics related to natural resource management, sustainable transport, socioeconomic balance and sustainable urban design. The interviewees were also asked about the specific local governance system in their neighbourhood, the implementation process for forming sustainable districts, the role and decision-making power of each stakeholder involved, community participation in planning and so on.

\section{Principles of new urbanism}

In this section, the basic characteristics of each sustainable neighbourhood are presented, with a special focus on urban design elements and sustainable design goals related to new urbanism principles. At the end of the section, the author identifies how these achievements and the urban design characteristics of each sustainable neighbourhood agree with the ten new urbanism principles (see Table 1). The aim is to verify whether the urban form in the neighbourhoods analysed is sustainably built (from the perspective of new urbanism).

Vauban in Freiburg is a neighbourhood with a population of five thousand in the foothills of the Black Forest. Seven hundred people work there (Fraker, 2013). It was built on the forty-two-hectare site of a former French military base. Vauban's bottom-up approach in planning allowed groups of potential residents to design their own homes on allocated plots of land alongside established developers. This has resulted in an architecturally non-uniform, non-standardised and picturesque district (Field, 2011).

Regarding sustainable energy and natural resource management, Vauban is an example of an efficient low-energy urban area and at the same time a space for innovation. At the edge of the neighbourhood, a local cogeneration plant (CHP) was built, which is fuelled by $80 \%$ woodchips (from a nearby forest) and $20 \%$ natural gas. Over $65 \%$ of the total electricity used in the district of Vauban is generated through photovoltaic panels, which are owned by the local residents grouped in various solar energy cooperatives (Sperling, 2002). In terms of building energy use, a mandatory low energy standard applies for both commercial and residential buildings $\left(65 \mathrm{kWh} / \mathrm{m}^{2}\right)$, and bottom-up initiatives for green technologies in buildings have been promoted and administered by local stakeholders in the neighbourhood. The neighbourhood has provided a 

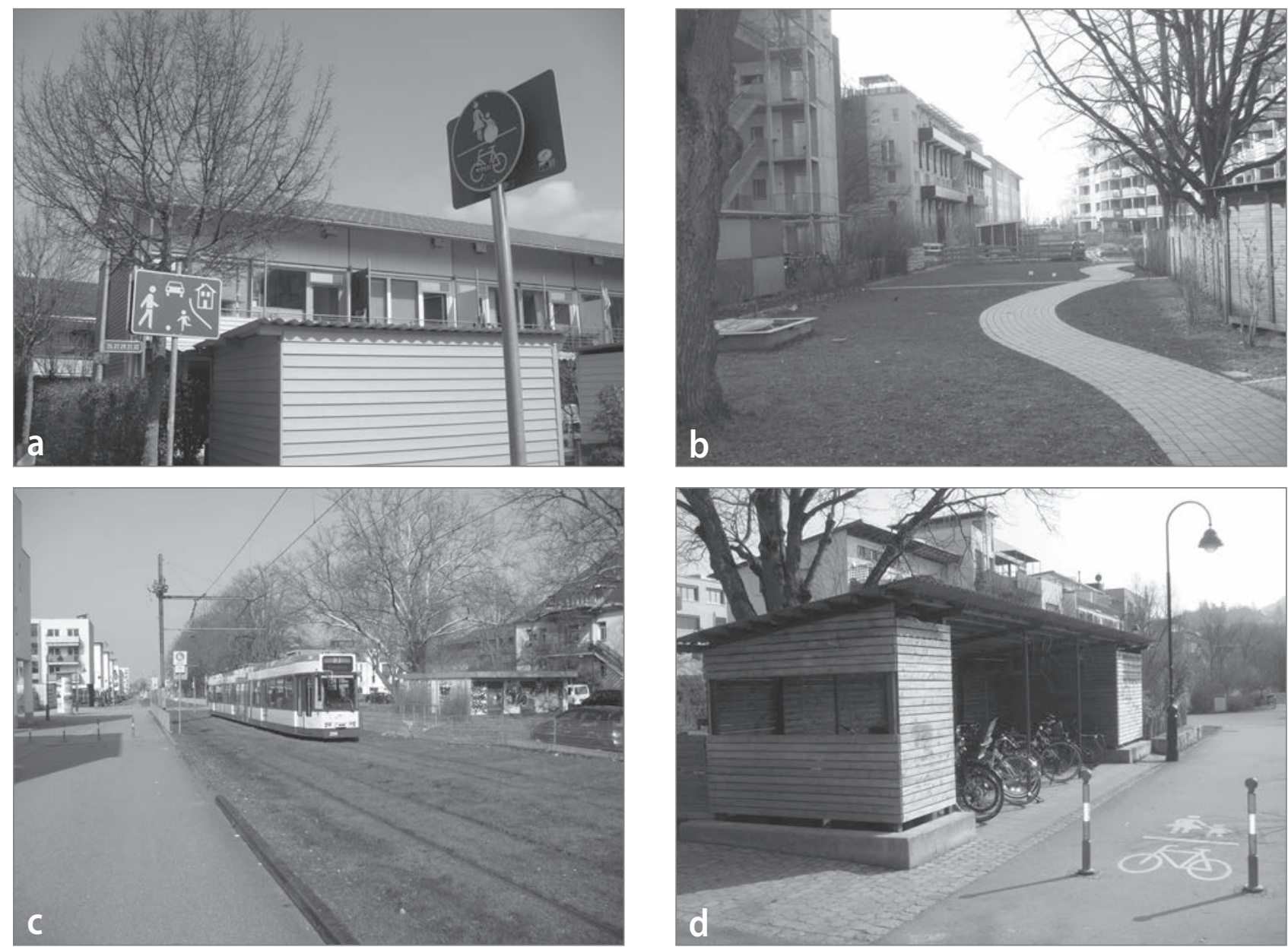

Figure 1: Vauban's sustainable transportation and car-free streets; a) a street as a playground; b) a car-free street; c) a tram; d) a bicycle shed (photo: Primož Medved).

testing ground for various techniques with the potential to reduce the consumption of natural resources and increase personal recycling. For example, in the experimental living lab in Vauban - Passivhaus Wobnen und Arbeiten - many innovative green technologies have been adopted, such as vacuum toilet systems and small biogas reactors for kitchen use (Internet 3; Delleske, 2013).

Transport in Vauban is shaped by the vision of life without a car, which promotes and stimulates alternative forms of mobility such as cycling initiatives, car-sharing systems and efficient public transport (Sperling, 2002). Vauban is completely integrated into a public transport network, with several city bus lines and the Freiburg tram (Figure 1c). The local urban plan practically prohibits parking in the neighbourhood of Vauban, where the roads are fully adapted to pedestrians and cyclists (see Figures 1a and 1d). The traffic policy in Vauban is supported by an effective car-sharing system. Because of all these local measures, laws, policies and environmental protection awareness of the locals, car ownership in Vauban is extremely low. Cars ownership per 1,000 people in Vauban is 150. In the Municipality of Freiburg, car ownership per 1,000 people is 427, and in Germany as a whole it is 517 (Sperling, 2008; World Bank, 2013).

Regarding urban design, Vauban succeeded in its initial goal to build densely, but green with plenty of parks, trees and open green spaces (see Figures $2 b$ and $2 d$ ). The population density (persons/ha) in Vauban is 122, and in the city of Freiburg it is 15 (Foletta, 2011; Banister, 2005). Urban plans aimed to create a living space where there is no need for cars and everything is at the doorstep, like in medieval towns (Daseking, 2013). The buildings primarily consist of three- to four-storey residential buildings. All ground-floor space is designed for service functions in order to provide basic life necessities to all residents of the neighbourhood.

Regarding public spaces, an important achievement of the civil initiative Forum Vauban was to set up an enormous collective space in the neighbourhood - the central neighbourhood community structure "Haus 037 " - which was restructured from the former French barracks (see Figure 2a). Haus 037 embodies a modern multifunctional facility, a heterogeneous public space with a restaurant, a pub, community meeting rooms, 

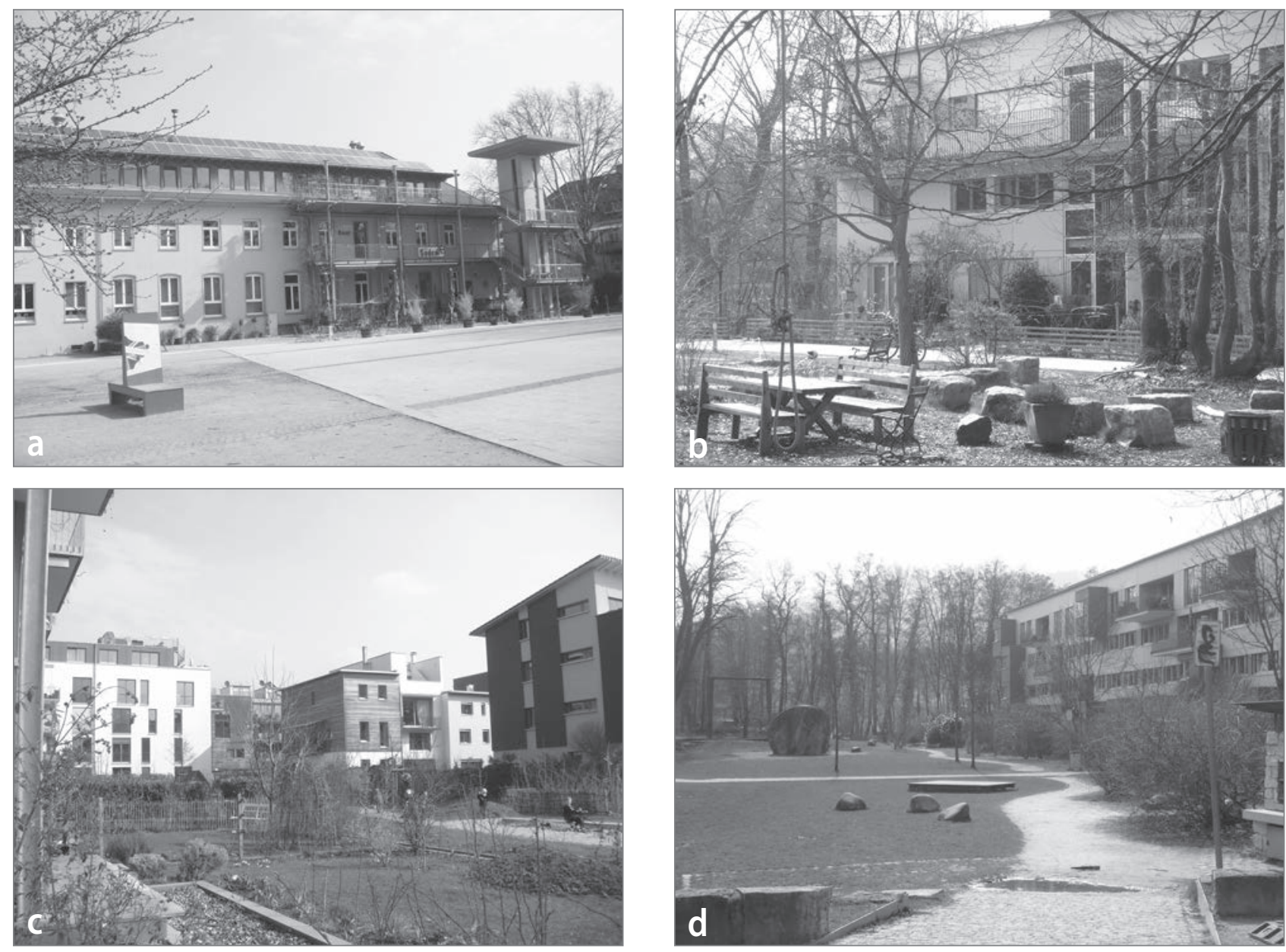

Figure 2: Vauban's public open spaces: a) the neighbourhood community centre Haus 037 and Vauban's Alfred Döblin Square; b) a park; c) an urban garden; d) a park (photo: Primož Medved).

offices and a hostel (Fraker 2013). Such a space strengthens the identity of the local urban space and offers the local residents a place where they can meet and communicate. Another important public space in Vauban is the central Alfred Döblin Square (Alfred-Döblin-Platz), which is located in front of Haus 037. Alfred Döblin Square is the heart of social life in Vauban, where the organic market (held twice a week) and exchange market (held once a month) take place. Vauban's approach to public urban spaces confirms the findings by Nataša Bratina Jurkovič (2014) that urban renovation plans implemented with the participation of a neighbourhood's residents diminish the risk of inappropriate or even poor programme planning.

Together with Hammarby Sjöstad in Stockholm, Western Harbour in Malmö is the most representative Swedish example of a sustainable neighbourhood. Western Harbour was primarily used as a port and industrial area, and was also home to the Kockums shipyard. The urban transformation process started with the closure of the Saab factory in 1990 at the original site of the Kockums shipyard, which freed up 140 hectares of attractive land near the centre and the sea. The area has now been developed into a modern neighbourhood with high sustainability ambitions. Western Harbour was developed in three stages: Bo01, Flagghusen (Bo02) and Fullriggaren (Bo03). The entire area of Western Harbour is still under construction. New sustainable construction is being created in the area. Currently, Western Harbour has 4,300 residents and provides jobs for nine thousand people (Foletta, 2011). The ratio of jobs per resident is very high if one compares it to similar sustainable neighbourhoods across Europe. When fully developed, thirty thousand people will work and study in the transformed urban area. Western Harbour is becoming a new student and economic centre of Malmö.

Regarding sustainable energy and natural resource management, the sustainable urban area in Western Harbour called the Bo01 district was the first sustainable neighbourhood in the world supplied by $100 \%$ renewable energy (Bächtold, 2013). Electricity is produced from solar and wind energy. The heating for Western Harbour comes mainly from the geothermal potential of groundwater $(80 \%)$ and partly from solar ener- 

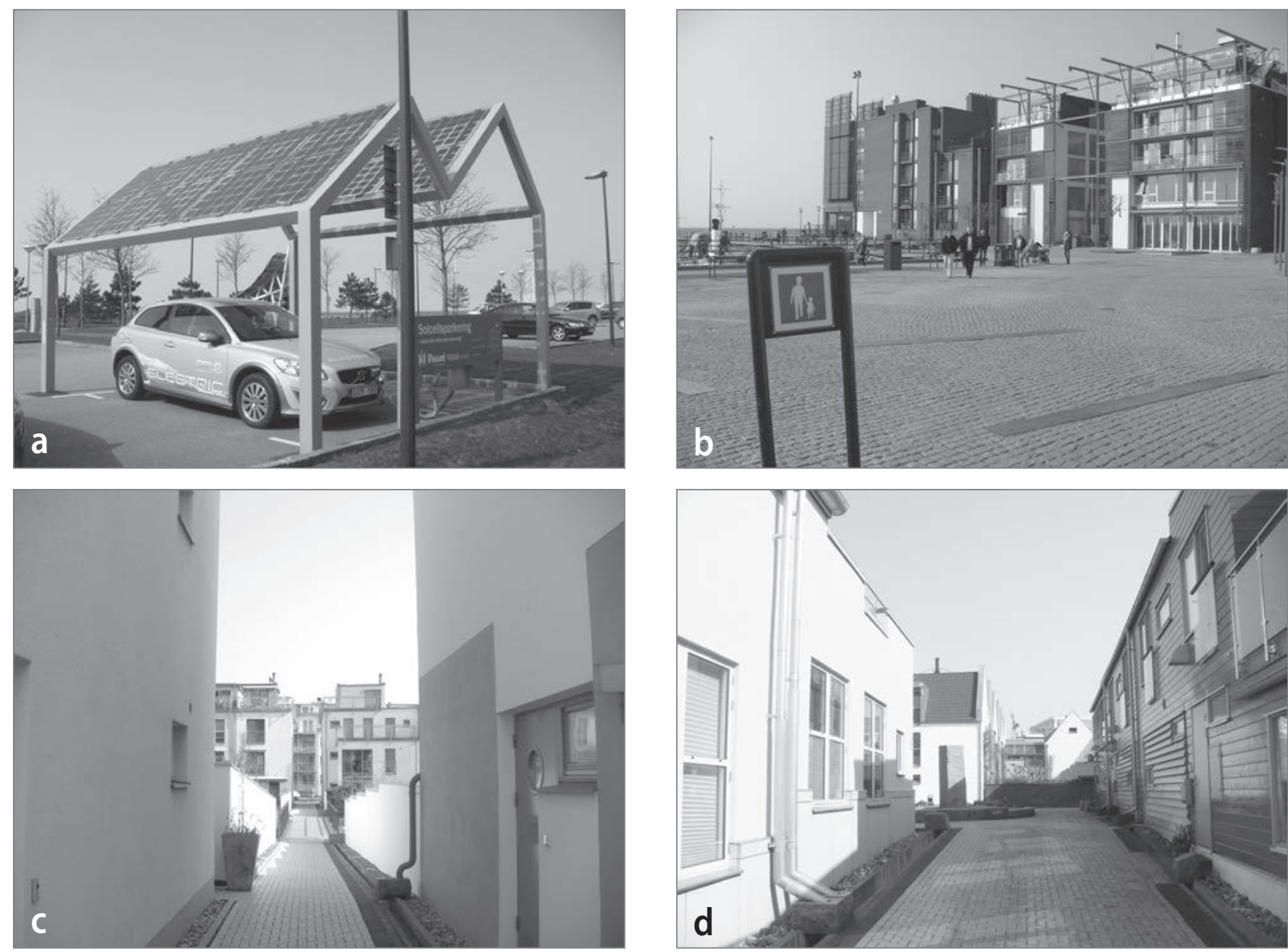

Figure 3: Western Harbour's sustainable transportation and car-free streets; a) an electric car sharing vehicle; b) a car-free public space; c) and d) car-free streets (photo: Primož Medved).

gy (15\%). Western Harbour is also a good example of applying green innovation to other areas than energy, especially to water and waste management. For example, in some buildings rainwater is used for washing clothes, for watering gardens and for flushing toilets (e.g., in the elementary school); domestic waste is transformed into a new energy source through a waste system with anaerobic vacuum digestion; organic waste is converted to biogas; and flat roofs are usually "green", covered with various vegetation (Bächtold, 2013).

Western Harbour's sustainable transport strategy begins, like in Vauban, with reducing car dependency. However, as recently as in 2011 the car ownership rate in Western Harbour was relatively high (440 cars per 1,000 residents), which is slightly less than the Malmö average (480 cars per 1,000; Foletta, 2011). In Western Harbour, cars are allowed in some streets, but the sustainable neighbourhood with a dense and vivid urban design tries to encourage walking and biking (Bächtold, 2013). A significant effort has been made to encourage bicycling and to improve the pedestrian network (see Figures $3 \mathrm{c}$ and $3 \mathrm{~d}$ ). Access to the harbour area from other suburbs of Malmö is provided by an efficient bus system running on biogas, electricity and natural gas. Parking is mainly provided through underground parking lots, with limited on-street parking. The parking ratio set by developers for the initial phase of Bo01 was 0.7 spaces per apartment in order to encourage walking, biking, and public transit use (Fraker, 2013; Zinkernagel, 2014). However, in later phases, because of resident pressure and market demand, the parking policy changed to 1.5 parking spaces per apartment. Neighbourhood residents can use the local car-sharing service (see Figure 3a), which has become very popular (Johansson, 2014; Lööf, 2014). In the development of Fullriggaren (Bo03), membership in a car-sharing scheme was included in the rent for the first two years. Recently, even "bike sharing" of cargo bikes has become popular in Western Harbour.

Regarding the architectural perspective, Western Harbour is inspired by urban design from the 1800 s with a relatively high population density. The population density (persons/ha) in Western Harbour is 57 and in the city of Malmö it is 19 (Foletta, 2011). Mixed-use buildings facing the main street have 

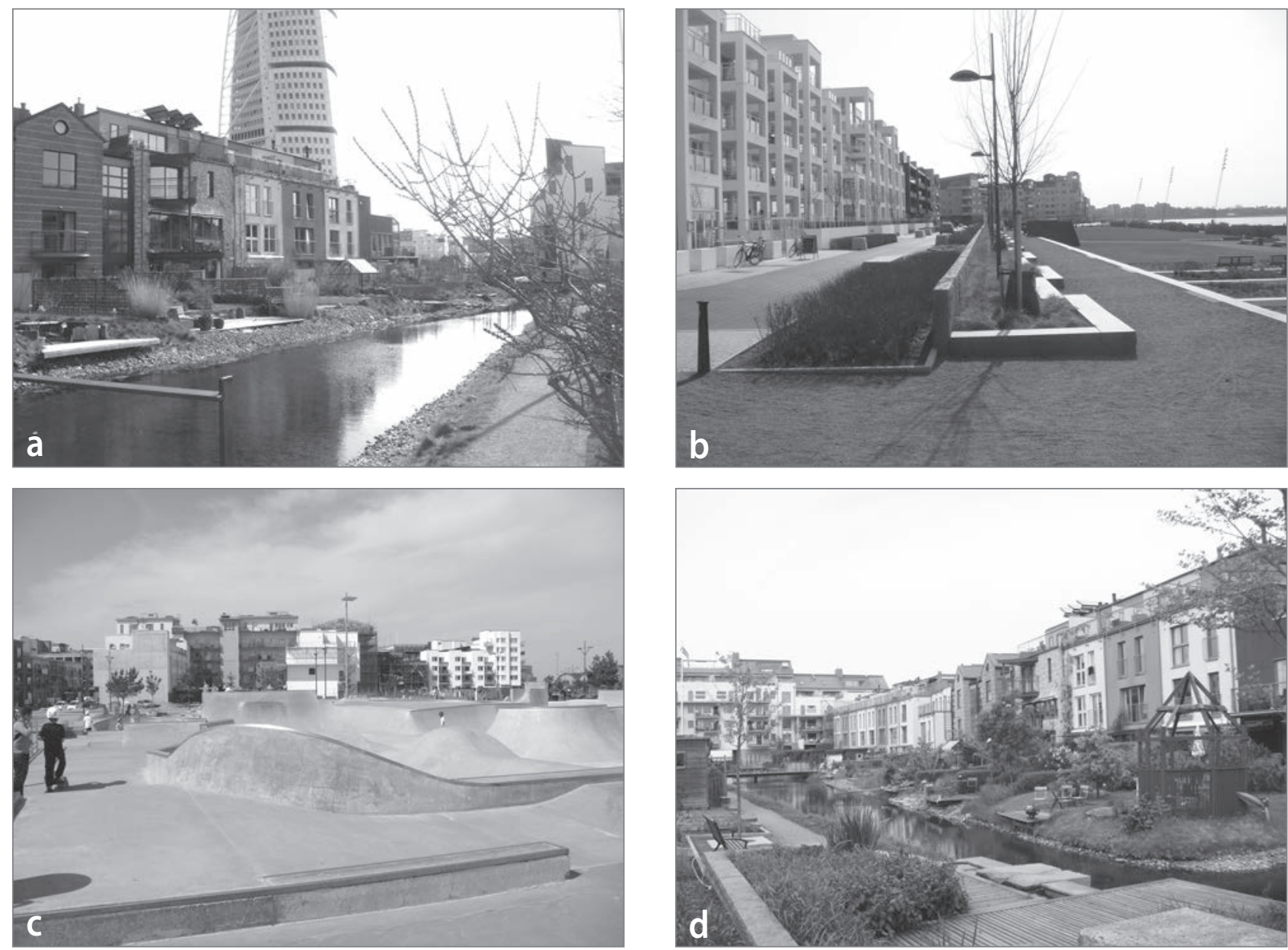

Figure 4: Western Harbour's public open spaces; a) a canal; b) promenade (Sundspromenaden); c) a skate park; d) a park (photo: Primož Medved).

residences, services or commercial spaces. There are six-storey buildings in the front, facing the sea, and low-rise buildings inside. In Western Harbour, like in Vauban, the urban design is also very heterogeneous. For the area of Bo01 alone, with 1,900 apartments, there were ten developers and twenty architects (Bächtold, 2013). Western Harbour is pedestrianfriendly with many interconnected streets and it has many green areas, a skate park (Figure 4c) and a large-scale open storm water system with canals, pools and fountains (see Figures $4 \mathrm{a}$ and $4 \mathrm{~d}$ ).

A strip of Western Harbour's waterfront has been converted into a popular public promenade. Although the concept at the beginning was disputable, today the promenade Sundspromenaden (Figure $4 \mathrm{~b}$ ) is an attractive place for citizens and visitors (Foletta, 2011). Sundspromenaden embodies the social role of an affluent convergent meeting place, like the central plaza in Vauban (Alfred Döblin Square). In contrast to Vauban, in Western Harbour there is no neighbourhood community centre for the local population.
The new urbanism movement especially promotes urban diversity and social heterogeneity within the urban environment. Therefore, a comparison of sustainable neighbourhoods also focuses on these aspects. From the urban design perspective of mixed building types, both neighbourhoods have achieved a very high level of diverse building typologies and public spaces (a promenade, plazas, urban gardens, skate parks, etc.). However, with regard to population heterogeneity, both neighbourhoods eventually failed to achieve (or maintain) a heterogenic social structure, and there is a risk that these sustainable neighbourhoods could become what Susan Fainstein (2010) calls "citadels of exclusivity". Especially in the initial years, Vauban succeeded in providing a considerable share of affordable housing (Fraker, 2013). Unfortunately, in recent times, rents in Vauban increased significantly, and Vauban is now among the most expensive residential areas in Freiburg. Consequently, most of its inhabitants today are educated professionals (Bächtold, 2013). Sigrid Gombert (2013) and Carsten Sperling (2008) also identified the switch in Vauban's social structure from the initial activists towards young upper-middle class families. However, the initial social urban structure (to a 
Table 1: Principles of new urbanism (Vauban and Western Harbour).

\begin{tabular}{|c|c|c|c|}
\hline $\begin{array}{l}\text { New urbanism } \\
\text { principle }\end{array}$ & Definition / factor of interest & Vauban & Western Harbour \\
\hline \multirow{3}{*}{ 1. Walkability } & Most things within a ten-minute walk of home and work & + & + \\
\hline & $\begin{array}{l}\text { Pedestrian-friendly street design (buildings close to the street; porches, windows } \\
\text { and doors; tree-lined streets; on-street parking; hidden parking lots; garages in a } \\
\text { rear lane; narrow, low-speed streets) }\end{array}$ & + & + \\
\hline & Pedestrian streets free of cars in special cases & + & + \\
\hline \multirow{3}{*}{ 2. Connectivity } & An interconnected street grid network disperses traffic and eases walking & + & + \\
\hline & A hierarchy of narrow streets, boulevards and alleys & + & + \\
\hline & A high-quality pedestrian network and public realm make walking pleasurable & + & + \\
\hline \multirow{2}{*}{$\begin{array}{l}\text { 3. Mixed-use and } \\
\text { diversity }\end{array}$} & $\begin{array}{l}\text { A mix of shops, offices, apartments and homes on site; mixed use within neigh- } \\
\text { bourhoods, blocks and buildings }\end{array}$ & + & + \\
\hline & Diversity of people in terms of age, income level, culture and race & - & - \\
\hline 4. Mixed housing & A range of types, sizes and prices in close proximity & + & + \\
\hline \multirow{3}{*}{$\begin{array}{l}\text { 5. Quality architecture } \\
\text { and urban design }\end{array}$} & Emphasis on beauty, aesthetics, human comfort and creating a sense of place & + & + \\
\hline & Special placement of civic uses and sites within the community & + & o \\
\hline & Human-scale architecture and beautiful surroundings nourish the human spirit & + & + \\
\hline \multirow{4}{*}{$\begin{array}{l}\text { 6. Traditional neighbo- } \\
\text { urhood structure }\end{array}$} & Discernible centre and edge & + & + \\
\hline & Public space in the centre & + & 0 \\
\hline & Importance of a quality public realm; public open space designed as civic art & + & + \\
\hline & $\begin{array}{l}\text { Transect planning: highest densities in the town (neighbourhood) centre; progres- } \\
\text { sively lower density towards the edge }\end{array}$ & + & + \\
\hline 7. Increased density & $\begin{array}{l}\text { More buildings, residences, shops and services close together for ease of walking, } \\
\text { more efficient use of services and resources, and a more convenient, enjoyable } \\
\text { place to live }\end{array}$ & + & + \\
\hline \multirow{2}{*}{$\begin{array}{l}\text { 8. Green transporta- } \\
\text { tion }\end{array}$} & $\begin{array}{l}\text { A network of high-quality trains/trams/buses connecting cities, towns and neigh- } \\
\text { bourhoods }\end{array}$ & + & + \\
\hline & $\begin{array}{l}\text { Pedestrian-friendly design that encourages greater use of bicycles, rollerblades } \\
\text { and walking as daily transportation }\end{array}$ & + & + \\
\hline \multirow{6}{*}{ 9. Sustainability } & Minimal environmental impact of development and its operations & + & + \\
\hline & Eco-friendly technologies, respect for ecology and the value of natural systems & + & + \\
\hline & Energy efficiency & + & + \\
\hline & Reduced use of non-renewable fuels & + & + \\
\hline & More local production & + & + \\
\hline & More walking, less driving & + & + \\
\hline 10. Quality of life & $\begin{array}{l}\text { Taken together these add up to a high quality of life well worth living, and create } \\
\text { places that enrich, uplift and inspire the human spirit }\end{array}$ & + & + \\
\hline
\end{tabular}

Source: Author, 2016. 
Table 2: Processes for urban experimentation

\begin{tabular}{|c|c|}
\hline Processes & Definition \\
\hline \multirow{2}{*}{ Making } & Conceiving, framing and operationalising the will to improve the urban milieu in relation to climate change \\
\hline & $\begin{array}{l}\text { The process of assembling socio-technical parts, elements and actors that form a "space of exception" and at } \\
\text { the same time a "space of innovation" }\end{array}$ \\
\hline \multirow[b]{2}{*}{ Maintaining } & Upkeep of experimental qualities and keeping unruly elements at bay \\
\hline & $\begin{array}{l}\text { Metabolic adjustment (methods applying experiments that attempt to reconfigure existing forms of circulati- } \\
\text { on) }\end{array}$ \\
\hline \multirow{2}{*}{ Living } & $\begin{array}{l}\text { Bringing into being distinct subjectivities, including multiple elements that are assembled in experiments and } \\
\text { create an "experimental subject" }\end{array}$ \\
\hline & $\begin{array}{l}\text { Experiments operate in uncertain terrains (totalising rationalities and alternative subjectivities are under con- } \\
\text { stant negotiation) }\end{array}$ \\
\hline \multirow{2}{*}{ ***Disseminating } & $\begin{array}{l}\text { Sharing experience with other urban areas and organisations, expanding knowhow to networks outside their } \\
\text { borders, serving as incubators of change and conveying sustainability to the wider city environment }\end{array}$ \\
\hline & $\begin{array}{l}\text { Introducing sustainable lifestyles, technological solutions to adjacent (and distant) districts, cities and regions } \\
\text { by using the neighbourhood as a showcase }\end{array}$ \\
\hline
\end{tabular}

Source: Bulkeley et al., 2015 (modified/regrouped by the author, 2016).

lesser extent) persists within the neighbourhood (Vauban's "social houses": SUSI, Haus 037, etc.). Western Harbour was also initially planned to be a heterogeneous and socially sustainable area (Kärrholm, 2011). Today, however, the neighbourhood is predominantly populated by upper middle-class people. The first settlement in the area (Bo01) in particular was clearly designed for upper-income families (Madureira, 2015).

The presentation of sustainable neighbourhood urban design characteristics shows that both neighbourhoods achieved most of the factors of interest encompassed in the new urbanism principles (Table 1). As described, the only factor (within the third principle: mixed use and diversity) that was not achieved in either of the neighbourhoods is connected with the diversity of people (in terms of age, income level, culture and race). Western Harbour did not achieve a full checkmark regarding the special placement of civic uses and sites within community because it has not implemented a very important urban design element: the neighbourhood community centre. It also fell short regarding public space in the centre because it has not created a main public meeting space in the centre of the neighbourhood.

\section{Processes for urban experimentation}

This section investigates urban experimentation as defined by Bulkeley et al. (2015), covering making, maintaining and living in order to analyse the local governance system in each neighbourhood. Disseminating is added as an additional activity to investigate (see Table 2). Studying these processes as part of the dynamic evolution of a neighbourhood is fundamental for the research because the "making" process clarifies the "conceiving momentum" of urban regeneration (the initial implementation strategy: top-down vs. bottom-up), which is the main independent research variable. The research also focuses on the impact that the implementation approach (the "making process") has on other subsequent processes.

\subsection{Making}

To understand the complex system of different actors and components in Vauban and Western Harbour, it is first necessary to understand the prerequisites, and the history and the development processes for these specific sustainable urban areas. In the beginning, both neighbourhoods represented "spaces of exception" in relation to common unsustainable urban practices. Both neighbourhoods were eco-labs in sustainable urbanism, or "spaces of innovation". However, the visions, planning strategies and development mechanisms were completely different between the two eco experiments, which involved different stakeholders in planning.

In 1993, the Municipality of Freiburg developed an urban plan to reconstruct the former French barracks into a modern sustainable neighbourhood called Vauban. The timing of the city plan for the neighbourhood transformation coincided with the establishment of the activist organisation SUSI, which occupied the abandoned military barracks in 1992 . The SUSI group and later the association Forum Vauban were the initiators of an autonomous sustainable neighbourhood in Vauban. A strong local community and good organisation between the initial residents was crucial in establishing a long-term (local) 
identity and in strengthening the sustainable orientation of the neighbourhood. During the "making" process, the Municipality of Freiburg recognised the association Forum Vauban as a legitimate partner and coordination entity in the planning process. The association Forum Vauban introduced more radical measures into the local urban master plan and achieved a ban on cars in the neighbourhood in order to create safe streets where children could play (Field, 2011). The energy concept was also developed through collaboration between the $\mathrm{Mu}$ nicipality of Freiburg, Forum Vauban and the Freiburg Energy Company (Bächtold, 2013). During the area's development, Forum Vauban supported various non-profit organisations, such as building cooperatives, and at the same time also initiated special food and energy cooperatives. Vauban embodies the radical-ecocentrist transition version, which proposes a grassroots, localist approach to deep social, environmental and cultural transformations (Audet, 2014).

The Western Harbour area was owned by the Municipality of Malmö, which wanted to transform this industrial area after the bankruptcy of many companies (Lööf, 2014). The purpose of the transformation was to create an example of sustainable urban development and to strengthen the image of Malmö as a place to live and invest (Madureira, 2014). The initiators of Western Harbour were not the residents that lived and worked in the area, but the government authorities (namely, the Municipality of Malmö). The public sphere had a very marginal influence on the urban plan of the area of Western Harbour. One reason identified is that the initial architectural plans created by the developers were very detailed from the beginning (Lööf, 2014).

The difference in the initiation process between Vauban and Western Harbour was in the degree of residents' involvement in creating the sustainable neighbourhood concept. The Vauban "learning while planning" participation process, managed by Forum Vauban, was a typical grassroots project with a bottom-up approach. In Vauban, although the city made the process possible, much greater influence was exerted by residents through building cooperatives (Germ. Baugruppen) in terms of setting higher standards, selecting the architect, directing the design and managing the construction. In contrast, for Bo01 and all of Western Harbour, the Municipality of Malmö engaged architect-developer teams and commercial building developers. Western Harbour shows a typical topdown approach in building design, in which the goals and objectives were set entirely by the city. The critics point out that the "making" process of the local transformation in Western Harbour entailed no (effective) participatory involvement from civil society.

\subsection{Maintaining}

"Maintaining" refers to two distinct but related forms of practice for "the maintenance phase of urban experiments" (Bulkeley et al., 2015). Bulkeley et al. (2015) define two forms of maintenance: upkeep and metabolic adjustment. Upkeep adjustment is more physical and direct; it involves mundane practices (removing waste, painting, etc.) with some more strategic interventions (energy investment and blocking of roads). In contrast, metabolic adjustment relates to methods in which the application of experiments attempts to reconfigure existing forms of circulation (Bulkeley et al., 2015). Metabolic adjustment can be seen in policy adaptations, technological development and the development of new cultural sensitivities, and may also be directed towards new ends and the adaptation of new urban contexts.

This article focuses on how concrete "experiments intervene to reconfigure network circulation through metabolic adjustment" (Bulkeley et al., 2015: 39). To explain the metabolic adjustment of Vauban, it is necessary to consider two main waves of adaptation and modification. The first one is related to the energy standards of the building cooperatives. Forum Vauban was particularly successful in encouraging self-builders to adopt a stricter ecological approach than the compulsory standard. Apparently, the $65 \mathrm{kWh} / \mathrm{m}^{2} / \mathrm{y}$ set by the Municipality of Freiburg was not stimulating enough, and Forum Vauban initiated an informal competition between the cooperatives to reduce the energy demand of future buildings (Delleske, 2013). Forum Vauban arranged free consultations at organised events and seminars to help and inform self-builders and homeowners by providing information on energy-saving techniques (Bächtold, 2013). Many members of the building cooperatives and developers set their own, more aggressive standards. The second metabolic adjustment of Vauban is based more on the composition of the neighbourhood population, which has slightly changed over the years. From the radical green activism of the first pioneers, Vauban is slowly moving toward a more family-oriented neighbourhood, but without losing its particular "holistic sustainable orientation". In addition, the initial driver behind the Vauban development, SUSI, is still completely integrated in the neighbourhood and today has an important role in the local community, offering affordable council estate rentals. However, the tendency toward gentrification is evident.

Through urban transformation, Western Harbour has also readapted itself many times by adopting specific metabolic adjustments. At the beginning of the sustainable transformation, Western Harbour had a poor image and it was often criticised by the media. A fenced park, a for-pay housing expo for the 


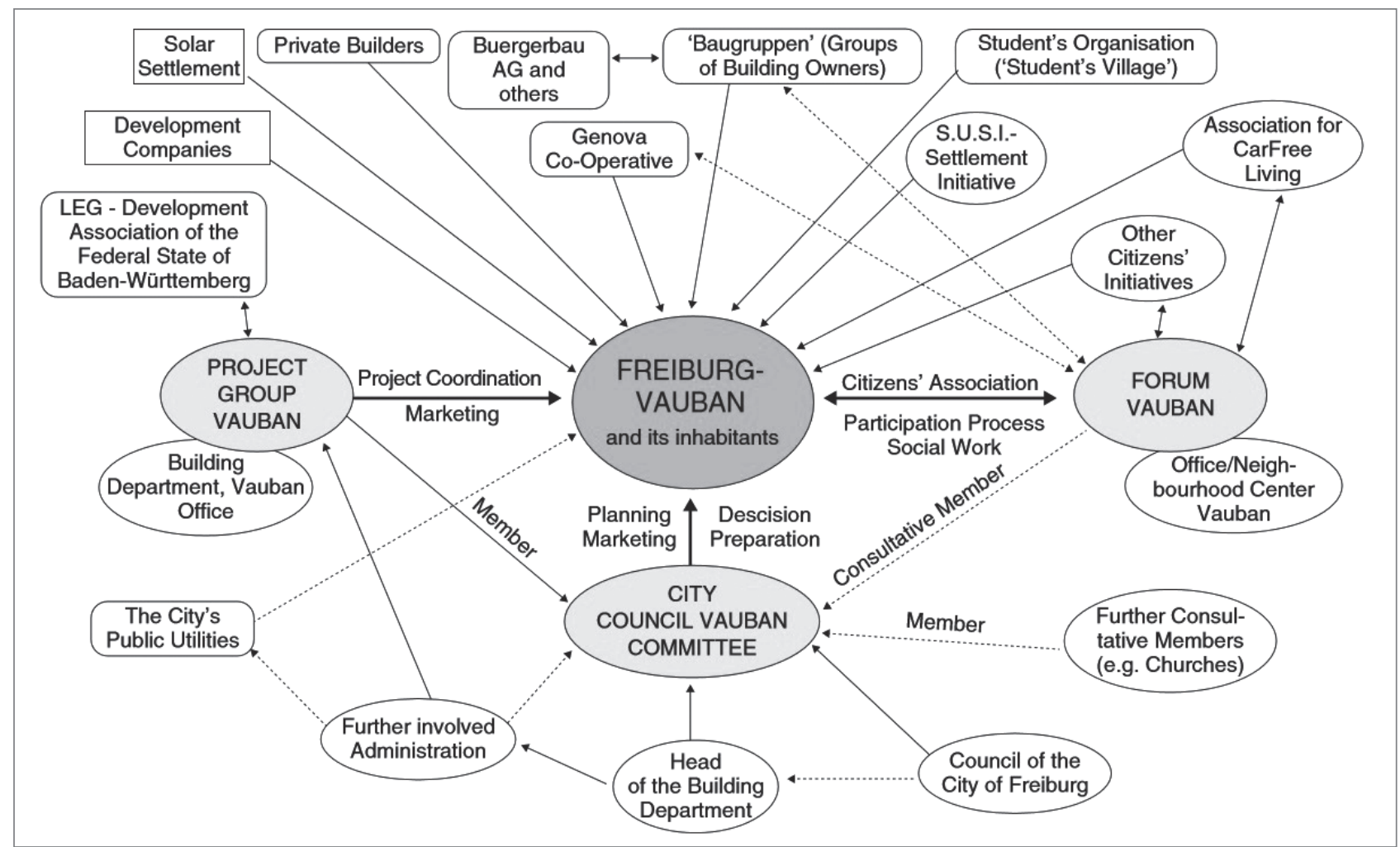

Figure 5: Vauban's local governance structure (source: Internet 2).

citizens of Malmö and consequently a boycott of it, financial scandals of building companies, unpaid local companies and the bankruptcy of the main developer are just some of the negative circumstances that accompanied the beginning of the urban transformation (Dalman, 2014; Lööf, 2014). Local criticism and the media also pointed to the high prices for the apartments and the consequent "ghettoisation" of the area (Holgersen, 2014). However, over the years Western Harbour has not only become a highly desired area to live in, but it has also become a central leisure (or recreation) spot in the city and a tourist attraction. The process of maintenance and metabolic adjustment is evident in how the neighbourhood reacted to its new role - that is, by providing special services such as bars, restaurants and so on. However, some local citizens were not very enthusiastic about this new openness to visitors and preferred a more closed local community (Dalman, 2014). The other aspect of reconfiguration during the experiment is shown in the behaviour of the Municipality of Malmö, which reacted to inaccurate predictions about the buildings' energy efficiency (Bächtold, 2013). The city responded to the unexpected situation with a variety of methods to change and improve residents' understanding of and commitment to sustainable development goals (Johansson, 2014).

\subsection{Living}

Living involves bringing into being distinct subjectivities, or multiple elements that are assembled in the experiment and create an experimental subject (Bulkeley et al., 2015). Both neighbourhoods are experimental living labs, but with a very different local governance system and different decisionmaking stakeholders. In Western Harbour, the main stakeholder and decision-maker is the Municipality of Malmö. It operates and manages the neighbourhood through its public institutions and with the cooperation of some private companies (such as E.ON), which perform various technical experiments in relation to the environmental solutions applied in low-energy housing, renewable energy grids and so on. In contrast, Vauban, through its citizens' participative associations Forum Vauban and SUSI, and through its various building cooperatives, renewable energy source cooperatives and various local citizens' organisations, has built up a multitude of interlaced stakeholders, which form a unique local governance system (see Figure 5). Vauban's local governance system, which encompasses many different stakeholders, has empowered local citizens.

Bulkeley et al. (2015) claim that experiments operate in uncertain terrain and are under constant negotiation. In Vauban, the association Forum Vauban experienced a serious existential threat and bankruptcy when the EU stopped funding its activities. However, in the end the legacy of Forum Vauban was able to recover under a different name: Stadtteilverein Vauban (Delleske, 2013). The constant negotiation processes and re-adaptation of the internal rules in the local "living" experiments could also be identified in Western Harbour. 
Because of the unplanned relatively homogenous social structure of the population in Bo01, the Municipality of Malmö negotiated a very specific "social contract" with the building developers for the subsequent developments. The Municipality of Malmö did not want Western Harbour to become "the golden coast of Malmö" (Dalman, 2014). They wanted to ensure that the continuation of Bo01 provided inclusivity. For this reason, the city wanted to build the cheapest rentals in Malmö. The city subsidised the land for the rentals in some parts of the Bo02 area. In return, the developers had to sign an agreement that they would not charge higher rent than the lowest quartile of the average rentals in Malmö. Unfortunately, the rents did not stay that low for long (Dalman, 2014). As mentioned before, Western Harbour (Bo01) experienced fragility and constant criticism at the beginning (especially from the media). However, after the initial stigma, the experiment of Western Harbour is now globally recognised as a success story of sustainable neighbourhood implementation. The creation of new forms of urban experiments seeks to create new expectations about what is (and is not) normal (Bulkeley et al., 2015).

\subsection{Disseminating}

Vauban and Western Harbour are sustainable neighbourhoods with a holistic approach to urban sustainability. For this reason, many cities around the world are eager to learn from Vauban and Western Harbour. The innovative disseminating process is important to the ongoing development of sustainable neighbourhoods because it entails sharing experience with other urban areas and organisations. Both neighbourhoods have directly and indirectly expanded their networks outside their borders. It is very complex to measure and define to what extent Vauban and Western Harbour have influenced the rest of their city, region and country with their urban sustainable approaches, and to what extent they have generated international impact. Some concrete actions, influences and knowhow that the two neighbourhoods have transmitted beyond their borders are presented below.

The disseminating process in the case of Vauban can be summarised in four forms of learning. First, knowledge about governance strategies and other organisational solutions has been transferred to other parts of the city (e.g., Rieselfeld) and to urban areas of other cities in the region (e.g., Französisches Viertel - Südstadt in Tübingen). For example, the Vauban building energy standard inspired the standard for energyefficient buildings in Rieselfeld. These standards formed the basis for a standard, which in 2009 came to apply for the entire city of Freiburg (Bächtold, 2013). Second, the creation of the first plus-energy multifamily house in the world is a technical solution that has been intensively analysed by urban planners, designers and architects. Third, the Vauban guided tours for tourists and researchers by local residents are a channel for spreading experience. The organisation of informational seminars about the development process of Vauban also promotes learning. Finally, the creation of the living lab Passivhaus Wohnen und Arbeiten (the first passive multi-dwelling house), including guided tours of the passive house, provided for more hands-on sharing of the sustainability solutions applied.

The disseminating process in the case of Western Harbour can be described in terms of three learning-related activities. First, knowledge about governance strategies and other organisational solutions has been transferred to other parts of the city (e.g., Hyllie and Augustenborg) and to other urban areas in the region (new plans for a sustainable neighbourhood in Lund; Dalman, 2014). Similarly to Vauban, the sustainable building standards developed throughout the different phases of Bo01 later formed the basis for a programme applying to all buildings developed on municipally owned land in the cities of Malmö and Lund (Smedby, 2016). Also, the builders' dialogue concept (with the social contract) between building developers and the Municipality of Malmö was transferred to the Municipality of Copenhagen (Lööf, 2014). Similarly, the approach to car sharing with a special contract concluded between the municipality, builders and a car sharing company was transferred to a different area of Malmö: Hyllie (Lööf, 2014). The Western Harbour traffic system has also become a model for the entire city of Malmö (Fraker, 2013). Second, in terms of more technical solutions, the waste digestion system that was developed in Western Harbour in Bo01 was used again in Bo03 and it will become a model for the entire city (Dalman, 2014; Lööf, 2014). Finally, guided tours of Western Harbour have been organised for thousands of international visitors.

\section{Conclusion}

Based on the new urbanism principles framework, it can be concluded that the bottom-up case of Vauban has achieved a human scale and community-oriented urban form very similar to the top-down case of Western Harbour. The initial implementation approach (top-down or bottom-up) did not influence the urban design form of the cases studied. Nearly all of the new urbanism principles were covered in both neighbourhoods. However, it is important to point out that in both neighbourhoods a fundamental aspect of new urbanism - that is, the diversity and heterogeneity of the urban population - has not been achieved. Based on a new urbanism analysis, the first hypothesis is rejected: that sustainable neighbourhoods with a bottom-up implementation approach create more human-oriented sustainable urban forms. In contrast, the top-down development in Western Harbour's urban form (see Table 1) is completely in line with new urbanism principles. Other top-down sustainable neighbourhoods 
across Europe (like Hannover's Kronsberg or Stockholm's Hammarsby Sjöstad) similarly have a very functional and sustainable dense urban structure, which encourages walkability, incorporates mixed-use buildings, is well connected with green urban transport, has many parks, offers plenty of (civil) services in the vicinity of residential areas and so on (Fraker, 2013). Therefore, it can be concluded that most of the new urbanism principles in sustainable urban neighbourhoods are attainable regardless of the initial implementation approach.

Based on the comparative analysis, it is possible to confirm the second hypothesis: that the sustainable neighbourhoods implemented with the participatory bottom-up approach generate stronger local governance systems and are more socially sustainable. Based on the processes framework, it can be established that the implementation approach (bottom-up or top-down) is relevant because it determines who (the citizen associations or the municipality) will act or react to the neighbourhood's daily progression or retrogression. It determines which stakeholder is the main protagonist and decision-maker for the neighbourhood. The analytical processes framework showed that in both case studies the initial development process (i.e., "making") directly influenced the subsequent processes and defined the final governance system and community social structure. Vauban's local residents have been the main decision-making stakeholders and, through building cooperatives and the association Forum Vauban, they set the social, economic and environmental targets for the whole area. In contrast, in Western Harbour, the entire area has been managed and developed by the Municipality of Malmö. Through the "maintaining" and "living" processes analysis, it could be established that the main stakeholders - the administrators or caretakers of the neighbourhoods - have not changed drastically over time.

The processes framework analysis also revealed that Vauban's bottom-up case study stimulated more socially sustainable organisations and activities, which have enabled the local community to express its vitality. Similarly, other European sustainable neighbourhoods implemented with the participative bottom-up approach (e.g., Amsterdam's sustainable neighbourhood GWL Terrein and Culemborg's EVA Lanxmeer) have also developed a very strong local urban identity and strong social cohesion, and have empowered local residents, who are now responsible for several neighbourhood issues. Therefore, for developing socially sustainable urban areas with strong community-driven local governance in the future it would be beneficial to include the participative dialogue in planning and include the community-based organisation in the urban development strategy from the beginning (in the "making" phase).
Regardless of the differences between the two neighbourhoods established in terms of their "making", "maintaining" and "living" processes, both have acted similarly in the "disseminating" process. There appears to be no significant difference in the transfer of knowledge processes between the case studies. Both sustainable neighbourhoods have successfully transferred technical knowhow (building energy standards, creation of a living lab, a waste digestion system, etc.) and shared their governance strategies and other organisational solutions (the builders' dialogue concept, car sharing, guided tours, etc.) to other urban communities.

Finally, the case studies provide a range of insights into the principles and processes of sustainable neighbourhoods. There is no universal solution or plan that can be followed when implementing sustainable neighbourhoods. Today both examples are internationally recognised as good urban sustainability models. In addition, both districts are living examples of the possibilities that can inspire cities and organisations around the world. Vauban and Western Harbour provide examples of diverse principles and processes that can be adopted to achieve a similar goal: sustainable neighbourhoods.

\section{Primož Medved \\ Ljubljana, Slovenia \\ E-mail: primozmedved@yahoo.com}

\section{References}

Audet, R. (2014) The double hermeneutic of sustainability transitions. Environmental Innovation and Societal Transitions, 11, pp. 46-49. DOI: 10.1016/j.eist.2014.02.001

Bächtold, P. (2013) The space-economic transformation of the city. Heidelberg, Springer. DOI: 10.1007/978-94-007-5252-8

Banister, D. (2005) Unsustainable transport: City transport in the new century. Abington, Routledge.

Barton, H., Grant, M. \& Guise, R. (2003) Shaping neighbourhoods: A guide for health, sustainability and vitality. New York, Spon Press.

Bayulken, B. \& Huisingh D. (2015) Are lessons from eco-towns helping planners make more effective progress in transforming cities into sustainable urban systems: A literature review (part 2 of 2). Journal of Cleaner Production, 109, pp. 152-165. DOI: 10.1016/j.jclepro.2014.12.099

Bratina Jurkovič, N. (2014) Perception, experience and the use of public urban spaces by residents of urban neighbourhoods. Urbani izziv, 25(1), pp. 107-125. DOI: 10.5379/urbani-izziv-en-2014-25-01-003

Bulkeley, H., Castán Broto, V. \& Edwards, G. (2015) An urban politics of climate change. London, Routledge.

Churchill, C. \& Baetz, B. (1999) Development of decision support system for sustainable community design. ASCE Journal of Urban Planning and Development, 125(1), pp. 17-35.

DOI: 10.1061/(ASCE)0733-9488(1999)125:1(17)

CNU \& HUD (2000) Principles for inner city neighborhood design: A collaboration of the Congress for the New Urbanism and the U.S. Department of Housing and Urban Development. San Francisco: Congress for the New Urbanism. 
Dalman, E. (2014) Interview about the development and characteristics of the sustainable neighbourhood Western Harbour (interview, 13 May 2014).

Daseking, W. (2013) Interview about the development and characteristics of the sustainable neighbourhood Vauban (interview, 7 Apr. 2013).

Delleske, A. (2013) Interview about the development and characteristics of the sustainable neighbourhood Vauban (interview, 6 Apr. 2013).

Fainstein, S. S. (2010) The just city. Ithaca, Cornell University Press.

Ferreira da Cruz, N. \& Marques, R. (2014) Scorecards for sustainable local governments. Cities, 39, pp. 165-170.

DOI: 10.1016/j.cities.2014.01.001

Field, S. (2011) Case study: Vauban. In: Foletta, N. \& Field, S. (eds.) Europe's vibrant new low car(bon) communities, pp. 94-106. New York, IDTP.

Flyvbjerg, B. (2006) Five misunderstandings about case-study research. Qualitative Inquiry, 12(2), pp. 219-245. DOI: 10.1177/1077800405284363

Foletta, N. (2011) Case study: Västra Hamnen. In: Foletta, N. \& Field, S. (eds.) Europe's vibrant new low car(bon) communities, pp. 82-93. New York, IDTP.

Forrest, N. \& Wiek, A. (2014) Learning from success - Toward evidenceinformed sustainability transitions in communities. Environmental Innovation and Societal Transitions, 12, pp. 66-88. DOI: 10.1016/j.eist.2014.01.003

Fraker, H. (2013) The hidden potential of sustainable neighborhoods. Washington, DC, Island Press. DOI: 10.5822/978-1-61091-409-3

Frey, H. (1999) Designing the city: Towards a more sustainable urban form. London, Spon. DOI: 10.4324/9780203362433

Gaventa, J. \& Valderrama, C. (1999) Participation, citizenship and local governance. Paper presented at Strengthening Participation in Local Governance, 21-24 June, Brighton. Typescript.

Gombert, S. (2013) Interview about the development and characteristics of the sustainable neighbourhood Vauban (interview, 7 Apr. 2013).

Grant, J. (2006) Planning the good community: New urbanism in theory and practice. London, Royal Town Planning Institute Library Series, Routledge.

Harvey, D. (1990) The condition of postmodernity. Cambridge, Blackwell.

Holgersen, S. (2014) The rise (and fall?) of post-industrial Malmö: Investigations of city-crisis dialectics. Lund, Lund University.

Internet 1: http://www.newurbanism.org/newurbanism/principles.html (accessed 20 May 2016).

Internet 2: https://www.oeko.de/ (accessed 18 May 2016).

Internet 3: http://www.passivhaus-vauban.de/ (accessed 20 May 2016).

Johansson, J. (2014) Interview about the development and characteristics of the sustainable neighbourhood Western Harbour (interview, 20 May 2014).

Kärrholm, M. (2011) The scaling of sustainable urban form: A case of scale-related issues and sustainable planning in Malmö, Sweden. European Planning Studies, 19 (1), pp. 97-112.

DOI: 10.1080/09654313.2011.530394

Kushner, J. A. (2002) Smart growth, new urbanism and diversity: Progressive planning movements in America and their impact on poor and minority ethnic populations. UCLA Journal of Environmental Law and Policy, 21(1), pp. $45-74$.

Kyvelou, S., Sinou, M., Baer, I. \& Papadopoulos, T. (2012) Developing a south-European eco-quarter design and assessment tool based on the concept of territorial capital. In: Curkovic, S. (ed.) Sustainable develop- ment - Authoritative and leading edge content for environmental management, pp. 561-588. Rijeka, Intech. DOI: 10.5772/45885

Lööf, M. (2014) Interview about the development and characteristics of the sustainable neighbourhood Western Harbour (interview, 9 May 2014).

Madureira, A. M. (2014) Physical planning in entrepreneurial urban governance - Experiences from the Bo01 and Brunnshög projects, Sweden. European Planning Studies, 22(11), pp. 2369-2388. DOI: $10.1080 / 09654313.2013 .843650$

Madureira A. M. (2015) Physical planning in place-making through design and image building. Journal of Housing and the Built Environment 30(1), pp. 157-172. DOI: 10.1007/s10901-013-9381-2

Medved, P. (2016) A contribution to the structural model of autonomous sustainable neighbourhoods: New socio-economical basis for sustainable urban planning. Journal of Cleaner Production, 120, pp. 21 30. DOI: 10.1016/j.jclepro.2016.01.091

Rahnama, M. R., Roshani, P., Hassani, A. \& Hossienpour, S. A. (2012) Use principles of new urbanism approach in designing sustainable urban spaces. International Journal of Applied Science \& Technology, 2(7), pp. 195-203.

Rogatka, K. \& Ramos Ribeiro, R. R. (2015) A compact city and its social perception: A case study. Urbani izziv, 26(1), pp. 56-66. DOI: 10.5379/urbani-izziv-2015-26-01-005

Rudlin, D. \& Falk, N. (2009) Sustainable urban neighbourhood: Building the 21st century home. Oxford, Architectural Press.

Smedby, N. (2016) Assessing local governance experiments for building energy efficiency - the case of Malmö, Sweden. Environment and Planning C: Government and Policy, 34, pp. 299-319. DOI: 10.1177/0263774X15614176

Sperling, C. (2002) Sustainable urban district Freiburg - Vauban. Available at: http://www.carstensperling.de/pdf/dubai-submission.pdf (accessed 8 Jun. 2016).

Sperling, C. (2008) Freiburg - Vauban; From military area to model district: Sustainable neighbourhood design - A communicative process. Newcastle: CABE Urban design summer school. Available at: http://webarchive.nationalarchives.gov.uk/20110118095356/http:/www.cabe.org. uk/files/udss2008-carstensperling.pdf (accessed 10 Jun. 2016).

World Bank (2013) Passenger cars (per 1,000 people). Available at: http:// data.worldbank.org/indicator/IS.VEH.PCAR.P3 (accessed 8 Jun. 2016).

Zinkernagel, R. (2014) Interview about the development and characteristics of the sustainable neighbourhood Western Harbour (interview, 9 May 2014). 